\title{
CENA LÍQUIDA: A ARTE TEATRAL EM ADERÊNCIA E RESISTÊNCIA À CONTEMPORANEIDADE
}

\section{Raphaela Silva Ramos Fernandes*}

* raphaelasramos@gmail.com

Mestranda em Artes pela Escola de Belas Artes da Universidade Federal de Minas Gerais (UFMG), especialista em Comunicação e Arte do Ator pela Faculdade de Comunicaçăo da Universidade Federa de Juiz de Fora.
RESUMO: No intuito de vislumbrar características da pósmodernidade espelhadas no teatro das últimas décadas, este artigo toma emprestadas metáforas de Zygmunt Bauman e pergunta-se: que cena aparece mergulhada nesta "modernidade líquida"? O exemplo utilizado para as discussões é o espetáculo Regurgitofagia, de Miche Melamed, em diálogo com livro homônimo de poesias.

PALAVRAS-CHAVE: Modernidade; teatro performativo; Michel Melamed; poesia.
RESUMEN: Conelpropósitodevislumbrarcaracterísticas de la posmodernidad reflejadas en el teatro de las últimas décadas, este trabajo toma por préstamo las metáforas de Zygmunt Bauman y se pregunta: ¿que escena aparece sumergida en esta "modernidad líquida"? El ejemplo utilizado para las discusiones es el espectáculo Regurgitofagia, de Michel Melamed, en dialogando con libro homónimo de poemas.

PALABRAS CLAVE: Modernidad; teatro performativo; Michel Melamed; poesía. 
1. MELAMED. Regurgitofagia, p. 19

2. MELAMED. Regurgitofagia, p. 101.

\section{ANTES DE MAIS NADA, TUDO}

Como se enfrentasse um sublime dilúvio, o mundo se desfaz. Encharca-se e perde as bordas; escorre. Mistura-se Agita-se. Doce e salgado. Faz-se lagoa e mar. Raso e profundo. A imagem, sugerida pelas inúmeras metáforas do teórico polonês Zygmunt Bauman, induz a certa compreensão da modernidade tardia, aquela que segue desde a segunda metade do século XX até os dias atuais. Potentes, as comparações propõem reflexões essenciais relativas ao homem de hoje e à sua maneira de se relacionar com o outro.

No intuito de tentar vislumbrar as características da fase pós-moderna espelhadas no teatro que vem sendo levado ao público nas últimas décadas, optamos, neste artigo, por tomar emprestadas as mesmas comparações de Bauman. Ao longo do texto, surgem, em itálico, palavras que nos conduzem à fluência dos novos tempos. Feito ondas indomáveis, identidades, informações, angústias e medos vêm e vão, apagando os rastros na areia.

"Porque tudo émetáfora para a vida", alerta Melamed. ${ }^{2}$ Dessa maneira, a mesma ideia de liquefação escolhida para a atualidade nos parece cabível como definição na passagem do moderno ao pós-moderno. Difícil seria precisar o momento em que o sólido começa a derreter. Muitos elementos próprios da primeira metade do século XX, aliás, são constatados hoje, porém, transmutados, seja pela tecnologia, seja pelos comportamentos que ela suscita. Logo, no primeiro item deste trabalho, procuramos apresentar algumas das principais questões da "modernidade líquida", na esteira da "modernidade sólida", com suas sombras e resquícios.

Ao traçar uma linha paralela, percebemos que, no percurso teatral, também escorrem, líquidas, as transições entre uma fase e outra. Segundo Glusberg (2011), a performance dos anos 1979, e tal qual compreendida hoje, remonta à antiguidade, possui uma pré-história. Adiante, já na vanguarda novecentista, futuristas, construtivistas, dadaístas e surrealistas anteciparam teatralizações performativas. Não há portanto, qualquer "marco zero". Sucedendo ao happening dos anos 1960, a performance se constitui híbrida, vicejando em solo duplo, ou melhor, na interseção entre artes plásticas e artes cênicas. Movendo-se de um ponto a outro e trazendo consigo experiências predecessoras como a body art, a performance concede ao teatro outras aquisições. E, conforme Féral (2008), este se beneficia com a oferta. Em tempos fluidos, já não é aceitável a rígida divisão entre os gêneros, as escolhas, as criações. Assim, a fim de espreitar o livre trânsito entre arte e mundo e entre as múltiplas artes, o segundo tópico procura entrelaçar contribuições de alguns autores a respeito da evolução do fazer teatral no século XX e neste princípio do XXI.
EM TESE
BELO HORIZONTE
v. 19
N. 1
JAN.-ABR. 2013
FERNANDES. Cena líquida: a arte teatral em aderência e resistência [...]
P. $208-226$

Crítica Literária, outras Artes e Mídias 
$\mathrm{Na}$ contemporaneidade, são postas em questão noções como drama, texto e palavra. Lehmann (2007), por exemplo, lança mão do termo "pós-dramático" para discutir o assunto Féral (2008), por sua vez, prefere a expressão "teatro performativo". Deste modo, optamos por reunir, em um mesmo cadinho, os conceitos dos dois autores e, ainda, a ideia de performance em profunda simbiose com o teatro sugerida por Cohen (1989 e 1998). Abordamos, aqui, certas manifestações, entre os muitos teatros de hoje, que se mostram respingadas de pós-modernidade. Na terceira parte do trabalho, buscamos, por conseguinte, agrupar as principais especificidades desse teatro intrinsecamente conectado à forma de vida atual e às inconformações que dela advêm. O exemplo utilizado para as discussões é o espetáculo Regurgitofagia de Michel Melamed, em diálogo com livro homônimo de poesias. Melamed aparece como sujeito influenciado pelo cotidiano pós-moderno e influenciador de resistências e indagações, valendo-se da intensa mobilidade entre teatro, performance, música, poesia e tecnologia.

No tópico seguinte, a presença - ou a ausência - da palavra nas obras teatrais contemporâneas assume o foco do debate, tendo ainda Regurgitofagia como paisagem para inserção e observação. Cabe afirmar que a dramaturgia não desaparece do espaço cênico, inclusive porque deixa de estar associada exclusivamente à ideia de texto escrito ou falado. De qualquer maneira, a palavra não está morta no teatro contemporâneo, mas, isto sim, desvinculada da lógica, da programabilidade e da referencialidade. Em sua montagem, Melamed trata de excessos. Palavras e silêncios. Disposto a "chocar" e a receber "choques", o artista deseja regurgitar frases e vazios. Comer seres e não-seres. Descomer pensamentos prontos, desaforos e paralisias. Recomer resistências, indignações e coragens. Enfim, devolver o que não serve e escolher melhor o que pode servir.

\section{ALGEMAS DERRETIDAS}

Segundo Zygmunt Bauman (2001), em Modernidade Líquida, os fluidos, por sua "extraordinária mobilidade", servem de principal e mais adequada metáfora para a presente fase da era moderna, iniciada nas décadas de 1960 e 70.

Os fluidos se movem facilmente. Eles "fluem", "escorrem", "esvaem-se”, "respingam”, "transbordam”, "vazam”, "inundam”, "borrifam", "pingam"; são "filtrados", "destilados"; diferentemente dos sólidos, não são facilmente contidos - contornam certos obstáculos, dissolvem outros e invadem ou inundam seu caminho. ${ }^{4}$

Valendo-se de tal paralelo, o teórico polonês assevera que, no tempo atual, toda liberdade sonhada e possível foi atingida. As convicções, entretanto, perderam-se entre antigos
3. Como explicado mais adiante, o artista tem os pulsos e os tornozelos ligados a uma "máquina de produzir choques" (interface apelidada pelo ator de "Pau-de-Arara"), por meio da qual reações sonoras da plateia são captadas por microfones e transformadas em descargas elétricas (www.michelmelamed. com.br).

4. BAUMAN. Modernidade líquida p. 8.
EM TESE $\quad$ BELO HORIZONTE $\quad$ v. $19 \quad$ N. $1 \quad$ JAN.-ABR. $2013 \quad$ FERNANDES. Cena líquida: a arte teatral em aderência e resistência [...] $\quad$ P. 208-226

\section{Crítica Literária, outras Artes e Mídias}


5. BAUMAN. Modernidade líquida p. 11.

6. O termo "segunda modernidade" foi cunhado por Ulrich Beck pela modernidade "voltandose para si mesma", a era da assim chamada "modernização da modernidade" (BAUMAN. Modernidade Líquida, p. 12).

7. BAUMAN. Modernidade líquida, p. 31.

8. PUCHEU. $A$ fronteira desguarnecida, p. 53.

9. Uma referência ao romance 1984, de George Orwell. vestígios. Dessa maneira, a já conhecida rigidez - própria do mundo sólido imediatamente predecessor - assume outra configuração e se mantém no caminho. De tão instáve e leve, a modernidade liquefeita esbarra na inflexibilidade. Uma contradição, portanto, emerge em destaque: "a rigidez da ordem é o artefato e o sedimento da liberdade dos agentes humanos. Essa rigidez é o resultado de 'soltar o freio"”.

Ao que parece, a liberdade sempre foi bênção e maldição As normas e as rotinas, agora efêmeras na "segunda modernidade", ${ }^{6}$ talvez sejam consideradas, de alguma maneira, capazes de poupar a agonia dos homens. Mas Bauman (2001) avisa: a liberdade sem precedentes chegou e, com ela a impotência também sem precedentes. Mais do que nunca, somos seres reflexivos e críticos. Nossa crítica, no entanto, é "desdentada, incapaz de afetar a agenda estabelecida para nossas escolhas na 'política-vida". ${ }^{7}$ Estamos sem limites, mas desengajados e em desencontro. Em seu livro A Fronteira Desguarnecida, Alberto Pucheu, seguindo nessa direção de pensamento, propõe uma simbiose - e um embate - entre o homem solitário e a cidade, que o recebe, mas o restringe em sua capacidade de experiência. "[...] Sob o testemunho pânico de alguns, uma desordem no corpo e nas coisas, uma fronteira desguarnecida entre a pessoa e a cidade".

No período da modernidade pesada, sintetizado pela fábrica fordista e pela onipresença do "Grande Irmão", 9 a teoria crítica procurava solapar a tendência totalitária de uma sociedade. De acordo com Bauman (2001), outros medos acompanharam o advento da livre fluidez. Os medos, também líquidos, escorrem hoje por todas as fendas do cotidiano (BAUMAN, 2006). Pucheu escreve (em texto que flui entre prosa e poesia): “[...] A parede aparentando vultos, e o medo da multidão desprendendo-se do cimento [...]”. ${ }^{10}$ Dentre os novos receios, segundo Bauman (2001), está a descrença na noção de fim do caminho e de coletivo. Assim, não obstante a interminável lista de meios disponíveis, os flutuantes e sedutores fins aparecem cada vez mais embaçados. A agonia e a incerteza escondem-se no excesso e na compulsão, não mais na falta de escolhas.

Conforme ressalta o autor, a apresentação dos membros como indivíduos é a marca registrada da sociedade moderna Porém, se na antiga modernidade a reacomodação em classes e a ação coletiva eram buscas frenéticas, na fase atual não são oferecidos lugares, e os indivíduos encontram-se cronicamente desacomodados. Stuart Hall (2006) concorda ao afirmar que as sociedades modernas do final do século XX tiveram fragmentadas suas paisagens culturais de classe, gênero, sexualidade, etnia, raça e nacionalidade, negando aos indivíduos sociais as antigas e sólidas localizações.

Para frustração daqueles que esperavam aumento de poder, a liberdade ilimitada exibe ar de impotência. Tudo é

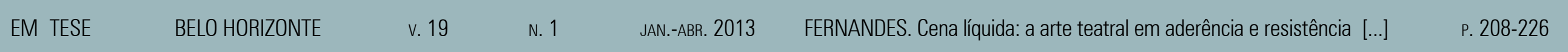

\section{Crítica Literária, outras Artes e Mídias}


11. BAUMAN. Modernidade líquida, p. 45.

12. BAUMAN. Modernidade líquida p. 62. permitido, e a escolha se faz insignificante. Dessa forma, na visão de Bauman "o indivíduo é o pior inimigo do cidadão". ${ }^{11}$ Tendo todas as possibilidades ao alcance das mãos, o sujeito percebe como restrição de seus desejos qualquer trabalho em conjunto. Ao se considerar único ocupante legítimo do espaço público, o ator individualizado o abarrota com suas preocupações e aflições não-aditivas. Os motivos que o levam para o palco público não são as causas comuns, mas sim a necessidade de fazer parte da rede e compartilhar intimidades, segredos, temores e ansiedades.

Aliás, nesse novo terreno - do público colonizado pelo privado - aparecem fincadas as principais mudanças trazidas pela "segunda modernidade". Curiosamente, no passado, a função da crítica era defender a autonomia privada contra a esfera pública. "Agora, é a esfera pública que precisa desesperadamente de defesa contra o invasor privado [...] - não para reduzir, mas para viabilizar a liberdade individual". ${ }^{12}$

Ser um indivíduo em meio à liquidez significa não ter ninguém a quem culpar pela própria miséria. Tudo se aloja sobre os ombros do sujeito. Uma vez que conviver com a auto-reprovação e o auto-desprezo não é tarefa cômoda, a atualidade mostra-se propícia aos bodes expiatórios e à culpa. A fim de aplacar, ainda que temporariamente, o sofrimento, recorre-se à figura do conselheiro, em substituição aos líderes do capitalismo pesado. O lugar antes ocupado pela ordem é agora destinado à tentação e à sedução, pois os conselheiros são "contratados" e podem ser "demitidos". Bauman enfatiza o poder do exemplo numa sociedade que lança foco sobre a experiência do outro para "descobrir e localizar os problemas que causaram nossa [...] infelicidade". ${ }^{13}$ As autoridades de hoje, fabricadas pelos próprios seguidores, podem ser conhecidas ou anônimas. Ferramentas como o Twitter, o Facebook e os programas de entrevistas citados pelo autor comprovam a afirmação anterior e legitimam o discurso público sobre questões privadas.

Outro recurso usado pelos atores individualizados para tentar encontrar a segurança e o fim da agonia é a sensação trazida pelo ato de comprar. $\mathrm{Na}$ "modernidade líquida", o "desejo" - mais fluido que a "necessidade" de outrora - concede espaço ao "querer": casual, inesperado e espontâneo, enfim, uma "substância naturalmente gasosa". ${ }^{14} \mathrm{O}$ consumismo, no entanto, não se expressa somente na aquisição de coisas. Os indivíduos estão livres para, à vontade, fazer e desfazer identidades e ser diferentes.

De acordo com Bauman (2001), em todos os tempos, a corrida em direção à identidade acontece na tentativa de solidificar o fluido. Entretanto, somente aos olhos alheios, vítimas da ilusão de ótica produzida pela distância, uma existência pode ser considerada lógica e consistente. "Essa obra de arte que queremos moldar a partir do estofo quebradiço
13. BAUMAN. Modernidade líquida, p. 78.

14. BAUMAN. Modernidade líquida, p. 89 .
EM TESE
BELO HORIZONTE
v. 19
N. 1
JAN.-ABR. 2013
FERNANDES. Cena líquida: a arte teatral em aderência e resistência [...]
P. 208-226

\section{Crítica Literária, outras Artes e Mídias}



15. BAUMAN. Modernidade líquida,
p. 97.

16. HALL. A identidade cultural na pós-modernidade, p. 13.

17. BAUMAN. Modernidade líquida p. 100.

18. Op. cit., p. 13 da vida chama-se 'identidade”. ${ }^{15}$ Stuart Hall acrescenta: “a identidade plenamente unificada, completa, segura e coerente é uma fantasia". ${ }^{16}$

No mundo líquido, as possibilidades de auto-identificação estão dispostas nas inconstantes prateleiras dos supermercados. Antes, aferrávamo-nos desesperadamente a coisas sólidas e duráveis na esperança de descobrir a unidade. $\mathrm{O}$ "mundo dos objetos duráveis", porém, foi trocado pelos "produtos perecíveis projetados para a obsolescência imediata". ${ }^{17}$ É preciso estar alerta para corresponder aos padrões cambiantes da vida lá fora. No entanto, submeter-se a normas velozes e flexíveis - seguindo as pegadas da sedução, não mais da coerção - não parece ser uma atitude livre. A "sociedade da entrevista”, portanto, traz à tona a obediência disfarçada de livre-arbítrio.

As identidades, assim, apresentam-se como oscilações contínuas e projetos nunca realizados. A cada dia, um "verdadeiro eu". Como sentencia Hall, as identidades modernas estão sendo continuamente deslocadas ou fragmentadas. "O sujeito assume identidades diferentes em diferentes momentos, identidades que não são unificadas ao redor de um 'eu' coerente" ${ }^{18}$ Esse talvez seja o paroxismo da liberdade na sociedade de consumo atual. Mas a rotina de quem escolhe (ou pensa escolher) nunca se distancia dos riscos, apesar da compensação trazida pelos recursos cada vez mais abundantes.

\section{TEATRO À PROVA D'ÁGUA}

Diante do exposto no item anterior, uma pergunta, naturalmente, vem à superfície: que teatro aparece mergulhado nessa "modernidade líquida"? Antes de tentar rascunhar uma possível resposta, iremos nos ater à visão de alguns autores a respeito da estreita relação entre arte e História. Segundo Hans-Thies Lehmann, "é [...] cego qualquer questionamento teatral que não reconheça na prática artística do teatro a reflexão sobre as normas de percepção e comportamentos sociais" ${ }^{19} \mathrm{O}$ teórico alemão lança tal reflexão como base para discutir o que nomeia de "teatro pós-dramático", tendo como referência determinadas manifestações ocorridas entre as décadas de 1970 e 1990.

Lehmann assevera que as vanguardas históricas em torno de 1900 já empregavam recursos de encenação abstratos, tidos como estranhos e que ressaltavam a insuficiência da palavra. Assim, características que, de forma recorrente, são atribuídas exclusivamente ao chamado "teatro pós-dramático”, já vinham sendo exploradas por criadores do início do século XX. Porém, apesar das inovações revolucionárias, a profunda ruptura das vanguardas ainda conservou o essencial do "teatro dramático".

Foi seguindo o intenso fluxo do desenvolvimento em todos os setores da vida contemporânea e consequentes mudanças como a onipresença da mídia no cotidiano que
19. LEHMANN. Teatro pósdramático, p. 21.
EM TESE
BELO HORIZONTE
v. 19
N. 1
JAN.-ABR. 2013
FERNANDES. Cena líquida: a arte teatral em aderência e resistência [...]
P. 208-226

\section{Crítica Literária, outras Artes e Mídias}


20. LEHMANN. Teatro pósdramático, p. 19

21. LEHMANN. Teatro pósdramático, p. 33.

22. PUCHEU. Escritos da frequentação, p. 29.

23. "Gostaria de lembrar aqui que seria mais justo chamar este teatro de 'performativo', pois a noção de performatividade está no centro de seu funcionamento" (FÉRAL, Por uma poética da performatividade: o teatro performativo, p. 197).

24. “Entretanto, se há uma arte que se beneficiou das aquisições da performance, é certament o teatro, dado que ele adotou alguns dos elementos fundadores que abalaram 0 gênero (transformação do ator em performer, descrição dos acontecimentos da ação cênica em detrimento da representação ou de um jogo de ilusão, espetáculo centrado na imagem e na ação e não mais sobre 0 texto, apelo à uma receptividade do espectador de natureza essencialmente especular ou aos modos das percepcõos próprias da tecnologia [..]" (FÉRAL, Por uma poética da performatividade: o teatro performativo, p. 198). a prática teatral, de fato, assumiu discurso "novo e multiforme" e submeteu o texto "às mesmas leis e censuras que regem os outros signos do teatro: visuais, auditivos, gestuais, arquitetônicos etc.” ${ }^{20} \mathrm{O}$ autor esclarece:

O adjetivo 'pós-dramático' designa um teatro que se vê impelido a operar para além do drama, em um tempo 'após' a configuração do paradigma do drama no teatro. Ele não quer dizer negação abstrata, mero desvio do olhar em relação à tradição do drama. 'Após' o drama significa que este continua a existir como estrutura - mesmo que enfraquecida, falida - do teatro 'normal'. ${ }^{21}$

Como se vê, tanto pela afinidade com a História quanto pelas definições em si, não é possível traçar limites claros na passagem do "dramático" ao "pós-dramático". Da mesma forma, não há fundamentos para uma divisão sólida entre moderno e pós-moderno. O que se introduz em um tempo, escorre pelo período seguinte, sendo desdobrado e questionado. Como lembra Pucheu, "[...] no duro combate, rixa e comunhão sinonimizam. [...] e a fronteira esvaecendo-se desguarnecida”. ${ }^{2}$

Josette Féral, que prefere substituir a expressão "teatro pós-dramático" por "teatro performativo" 23 e destaca a transferência do termo "ator" para "performer", ${ }^{24}$ também aponta o pioneirismo de alguns diretores e autores da primeira metade do século XX, os quais já haviam operado na dianteira elementos cênicos atuais - como, para nos limitarmos a um exemplo, a dissociação entre discurso (verbal ou visual) e sentido -, comprovando essa linha esfumaçada que liga a modernidade à pós-modernidade. Dessa maneira, as vanguardas novecentistas e (já na década de 1970) a performance arte abalaram a noção de teatro que deságua na época presente.

Avistando esse percurso dialógico, Féral (2008) cita Robert Lepage ${ }^{25}$ como um criador para quem o teatro deve dar conta da evolução dos modos de narração, percepção e compreensão do mundo. De que mundo, porém, estamos falando aqui? Do mundo traduzido pelo fragmento e abarrotado por imagem, mídia e tecnologia. Segundo Cohen, cabe ao artista, inserido nessa paisagem, "captar uma série de 'informações' que estão no ar e codificar essas informações, através da arte, em mensagem para o público. Essa codificação não implica limitação, mas, isto sim, retransformação através de outros canais". ${ }^{26}$ Logo, o artista seria uma espécie de relator de seu tempo, dando "tessitura às fraturas pós-modernas, estabelecendo continuum nas descontinuidades, permeando intensamente as ambiguidades arte/vida" ${ }^{27}$ Porém, ele não retrata, mas cria realidades a partir de outro ponto de vista: refletindo, criticando, inconformando-se e propondo
25. Ator, roteirista e cineasta canadense, nascido em 1957 Fundador da companhia Ex Machina.

26. COHEN. Performance como linguagem: criação de um tempo-espaço de experimentação, p. 87.

27. COHEN. Work in progress na cena contemporânea, p. XXIV.

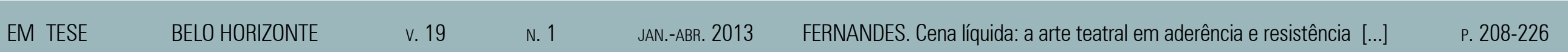

\section{Crítica Literária, outras Artes e Mídias}


29. FÉRAL. Por uma poética da performatividade: o teatro
performativo, p. 205-6.

30. COHEN. Performance como linguagem: criação de um tempo-espaço de experimentação, p. 58 embates. "Porque - diferentemente dos ávidos antropófagos - já deglutimos coisas demais”. ${ }^{28}$

\section{ARTE DA ESOUIVA}

O título deste tópico, uma expressão utilizada por Féral (2008), refere-se ao teatro dos tempos líquidos. Ao que parece, as metáforas de Bauman também se aplicam à cena contemporânea: "o que o espectador olha, e aquilo pelo que ele se deixa seduzir, é precisamente esta arte da esquiva, da falsa aparência, do jogo em que ele está precisamente num lugar onde não sabia que estava. Ele descobre assim a força da ilusão”. ${ }^{29}$

Conforme já mencionado, para Hall (2006), qualquer noção de totalidade associada à identidade trata-se de uma quimera. Somente aos olhos alheios um indivíduo pode se fazer coerente. O teatro de hoje parece suprimir a ilusão de ótica causada pela distância em relação ao outro, permitindo que as identidades cênicas habitem um "entrelugar" e exponham aos espectadores seus pedaços desconexos, seus excertos inconstantes.

Segundo Cohen, "o performer, enquanto atua, se polariza entre os papéis de ator e a 'máscara' da personagem". ${ }^{30}$ Oscilante, percorre inúmeras figuras, já que, em cena, ele mesmo não diz respeito ao "homem do dia a dia". O ator é também uma máscara. Não se pode afirmar, portanto, que o performer "faz a si mesmo". Ele representa ou simboliza algo em cima de si mesmo, o que, conforme Cohen (1989), é denominado pelos americanos de self as context. ${ }^{31} \mathrm{O}$ corpo performativo não para de vibrar entre vida e não-vida.

Questionando o Paradoxo sobre o Comediante, de Denis Diderot, que enuncia a impossibilidade de ser e representar simultaneamente, Cohen (1989) enfatiza que

À medida que o ator entra no "espaço cênico" ele passa a "significar" (virar um signo) e com isso "representar" (é o próprio conceito de signo, algo que represente outra coisa) alguma coisa, podendo ser isso algo concreto - o qual se tem nomeado personagem - ou mesmo abstrato (como as figuras que aparecem em peças surrealistas, por exemplo, Les Mamelles de Tirésias, de Apollinaire). ${ }^{32}$

A esse respeito, Barba (1994) classifica como "sorte rara" o fato de o ator possuir o dom da ubiquidade, reunindo em si, quando em atuação, as ações físicas ${ }^{33}$ e as associações pessoais. Em outras palavras: o performer acumula em um só corpo o que de antemão está exposto ao público e uma parte apenas sua, que pode ser revelada ou, por outro lado, nunca alcançar a percepção do olhar externo.

No espetáculo Regurgitofagia, ${ }^{34}$ Michel Melamed, único a ocupar o espaço cênico, veste-se de preto e tem os pulsos e
31. SCHECHNER. Post moder performance - two views Performings Arts Journal, p. 16

32. Op. cit., p. 95.

33. Desdobramento do conceito de Constantin Stanislavski (1863-1938).

34. Primeira parte da Trilogia brasileira. Estreou em abril de 2004 no Rio de Janeiro.
EM TESE
BELO HORIZONTE
v. 19
N. 1
JAN.-ABR. 2013
FERNANDES. Cena líquida: a arte teatral em aderência e resistência [...]
P. 208-226

\section{Crítica Literária, outras Artes e Mídias}


35. www.michelmelamed.com.br.

36. MELAMED. Entrevista concedida para pesquisa de mestrado, 24 para pesq.
jan. 2013. os tornozelos ligados a uma "máquina de produzir choques" (interface apelidada pelo ator de "Pau-de-Arara"), por meio da qual reações sonoras da plateia são captadas por microfones e transformadas em descargas elétricas. ${ }^{35}$ Como precisar essa figura verborrágica e provocadora? "Sou 'eus' e uns personagens. Às vezes conscientemente, outras não. [...] parece que tudo precisa de um movimento contínuo entre extremos. Seja na criação ou na performance, não há cristalização, não há um entendimento único, não há verdade essencial". ${ }^{36}$

Assim como os choques descarregados sobre o corpo de Melamed também "atingem" a plateia provocando uma reação ininterrupta em cadeia (Melamed $\rightarrow$ plateia $\rightarrow$ Melamed $\rightarrow$ plateia), o trânsito entre dentro e fora de possíveis personagens leva a um jogo de forças contínuo que oferece, aos espectadores, dois polos produtores de eletricidade: o real e o ficcional. Afinal, as descargas elétricas realmente alteram o corpo do ator, que não imita ou representa enquanto se agita em função do choque. Por outro lado, ele tampouco frequenta seu espaço habitual e vive seu tempo cotidiano.

Para Féral (2008), duas forças se originam no centro da obra performativa. Uma é seu caráter de descrição dos fatos, a outra se refere às ações que o performer executa. Tais ações lançam o público ao real, mas, em paralelo, o fazem desconstruir esse real e ter contato com o ficcional. "Essa desconstrução passa por um jogo com os signos que se tornam instáveis, fluidos, forçando o olhar do espectador a se adaptar incessantemente, a migrar de uma referência à outra, de um sistema de representação a outro, inscrevendo sempre a cena no lúdico e tentando por aí escapar da representação mimética" ${ }^{37}$ (grifo nosso).

A plateia vê Melamed acoplar, às extremidades de braços e pernas, os fios da "máquina de choques". O artista age. Mas o que pretende, o que quer "dizer"? De acordo com Féral (2008), diante desse fazer, dessas ações postas em cena, só resta ao espectador encontrar algum sentido. "A atenção do espectador se coloca na execução do gesto, na criação da forma, na dissolução dos signos e em sua reconstrução permanente" ${ }^{38}$ As ambiguidades de significações, portanto, tornam-se peças de um jogo labiríntico cujos jogadores, numa referência a Bauman (2001), estão absolutamente livres para escolher.

Com relação às ações, Barba (1994) observa que elas não possuem significado por si mesmas, ainda que seja impossível ao público estar diante do ator sem produzir sentidos ou imaginar histórias. No entanto, nesse caso, está em foco o ponto de vista do espectador, sempre associado à noção de resultado. Conforme o teatrólogo, se a lente for ajustada sobre o processo criativo do ator, pode-se questionar se o mesmo deseja ou não programar significados. "É evidente que o ator pode trabalhar as suas ações (dicção, tonalidade, porte,
37. FÉRAL. Por uma poética da performatividade: o teatro performativo, p. 203.

38. FÉRAL. Por uma poética da performatividade: o teatro performativo, p. 209.
EM TESE $\quad$ BELO HORIZONTE $\quad$ V. $19 \quad$ N. $1 \quad$ JAN.-ABR. $2013 \quad$ FERNANDES. Cena líquida: a arte teatral em aderência e resistência [...] $\quad$ P. 208-226

\section{Crítica Literária, outras Artes e Mídias}


volume, distância, intensidade) sem pensar no que gostaria de transmitir ao espectador uma vez que esteja terminado o processo". ${ }^{39}$

Aí está, segundo Vendramini (2001), o ponto exato da diferença entre o teatro tradicional e o que ele aponta como "não-dramatúrgico". No primeiro caso, mesmo que ator, autor e encenador trabalhem, por exemplo, a não-linearidade, a combinatória das partes será, de antemão, decidida por eles para ser entregue, com sentido "obrigatório", "pré-moldado", ao público.

Distanciar-se do ponto de vista do espectador e dos resultados é, segundo Barba (1994), uma maneira de compreender o caminho e o corpo-mente utilizado na caminhada. Durante o processo, o ator, imerso em um treinamento diverso daquele comum ao teatro ilusionista, pode intervir como se o objetivo primordial fosse a energia, a presença, não o significado ou a pretensão de dominá-lo. Conforme Barba (1994), uma vez que a condição para o brotar de sentidos se dá a partir da relação ator-espectador, antes de representar, o ator deve "ser".

Por conseguinte, e levando em conta tudo o que foi discorrido neste item do trabalho, podemos considerar que "ser" e "fazer" são verbos constitutivos do teatro contemporâneo sempre conjugados no presente. Tal teatro reencontra o presente ao desejar produzir evento e dissolver o referente (que, naturalmente, nos levaria ao passado ou ao futuro). "A peça não existe senão por sua lógica interna que lhe dá sentido, liberando-a, com frequência, de toda dependência, exterior a uma mímesis precisa, a uma ficção narrativa construída de maneira linear. O teatro se distanciou da representação". ${ }^{40}$

Estar na plateia do espetáculo Regurgitofagia pressupõe testemunhar choques, presenciar o inesperado que não se repete. Que palavra ou trecho provoca riso ou indignação no público? Não se sabe. O fato é que os motivos detonadores da "troca" de eletricidade se justificam e possuem validade apenas naquele instante, na comunhão específica entre o ator e cada grupo de espectadores. Cohen (1989) destaca que a característica de evento do teatro contemporâneo acentua a cumplicidade entre performer e público, inserindo-os em um confronto cara a cara. Assim, o "acontecimento" pinça o momento presente na linha dinâmica do tempo, criando uma ruptura de continuidade que, por si só, gera algum sentido.

No dicionário, ${ }^{41}$ a palavra evento surge como sinônimo de sucesso, êxito. De acordo com Féral (2008), porém, estar presente, na obra performativa, equivale a assumir os riscos e os malogros reais do fazer. A ação pode se efetivar ou não. Diante dos espamos de Melamed, não há como deixar de questionar se o ator corre perigo. Porém, como
40. FÉRAL. Por uma poética da performatividade: o teatro performativo, p. 209.
EM TESE
BELO HORIZONTE
v. 19
N. 1
JAN.-ABR. 2013
FERNANDES. Cena líquida: a arte teatral em aderência e resistência [...]
P. 208-226

\section{Crítica Literária, outras Artes e Midias}


42. MELAMED. Regurgitofagia, p. 121. explicita Bauman (2001), a responsabilidade pelas escolhas está apoiada exclusivamente nos ombros do sujeito, de modo que a plateia permanece no embate, mas responsabiliza-se apenas pelos "choques" que recebe. Contudo, rir, gritar ou silenciar para evitar o sofrimento do artista são alternativas disponíveis.

Semelhantes às identidades - de todos os tempos e, com mais veemência, as da chamada "modernidade líquida" as obras performativas permanecem abertas, são processos ininterruptos, pois se transformam a partir de feedbacks. Retornando às afirmações de Bauman (2001), podemos considerar que o território teatral irá refletir e questionar a especificidade pós-moderna de irrelevância dos fins. Fora e dentro da cena, ninguém sabe ao certo aonde quer chegar, embora todos conheçam pormenorizadamente os meios que permitiriam a conclusão do trajeto. Entretanto, "[...] não há um só caminho, uma só bandeira - mas um excesso de mastros". ${ }^{42}$

Nas criações denominadas Work in Progress (COHEN, 1998), o que interessa é o "processo" e não o "produto". A acentuação da ausência de ponto de chegada, talvez, implique no surgimento de uma pergunta em voz alta: afinal, o que desejamos? Ou mesmo: para que servem os pontos de chegada? Se pensarmos que, em muitas situações de hoje, a arte também é vista como um objeto disponível ao efêmero "querer" (BAUMAN, 2001), a focalização no "como" e não no "o que" (COHEN, 1989) passa a ser percebida como uma atitude de resistência e de transferência do "entender" para o "sentir". Como salienta Melamed: "não fazemos o trabalho premeditando se o público vai gostar ou não, como se fosse um produto na prateleira do supermercado". ${ }^{43}$

Uma vez que ao ator já não cabe a tarefa única de oferecer uma personagem bem delineada ao espectador, resta ao primeiro "dar de si", acessando as gavetas com conteúdos pessoais, os quais nos aponta Barba (1994). Se, por um lado, roteiros são elaborados a partir do ego (self as context) e de uma visão particular de mundo, por outro, há o desgaste físico e a exposição de habilidades pessoais (COHEN, 1989). No caso de Melamed, o investimento de si se faz desde a organização do texto (criado como um livro de poesias homônimo e que mostra sua maneira de suspeitar da vida), passa pela co-direção (ao lado de Alessandra Colasanti e Marco Abujamra) e, por fim, alcança o espaço da atuação, no qual o artista se expõe solitário e disposto a trocar descargas elétricas a partir da "voz" do receptor. Em Regurgitofagia, há, segundo pensamento de Cohen (1998), um acúmulo de autoria.

Na pós-modernidade, inúmeros conceitos modernos foram examinados e revistos com outra tecnologia (COHEN 1989). Vivemos o tempo dos aparelhos eletrônicos, dos conteúdos digitais, das conversas virtuais e da instantaneidade,
43. MELAMED. Entrevista publicada no jornal $O$ Globo.
EM TESE
BELO HORIZONTE
v. 19
N. 1
JAN.-ABR. 2013
FERNANDES. Cena líquida: a arte teatral em aderência e resistência [...]
P. 208-226

\section{Crítica Literária, outras Artes e Mídias}


44. BAUMAN. Modernidade líquida p. 36.

45. Bauman (2001), por sua vez, associa a obra 1984, de George Orwell, às características modernidade sólida, com "Grande Irmão".

46. A resistência, segundo Eleonora Fabião, deve estar sempre conectada à ideia de aderência. Resistir à realidade, pertencendo a ela. Informação obtida na palestra Condução de trabalho: pedagogias, treinamentos e pedagogias, treinamentos e II Simpósio de Reflexôes Cênicas Contemporâneas, Unicamp, Campinas, em 20 fev. 2013)

47. A americana "Marianne Weems [...] fundou em 1994 a companhia Builders Association, após ter sido dramaturga e assistente de Elizabeth (FÉRAL, Por uma poética da performatividade: o teatro performativo, p. 206) ou, como diria Bauman (2001), da "irrelevância do espaço, disfarçada de aniquilação do tempo" ${ }^{44}$

Segundo Cohen (1989), a principal razão para a "eletronificação" da performance é o seu pendor para a resistência Posicionar-se contra a voz eletrônica, fragmentada e subliminar do sistema, que Cohen (1989) compara à voz orwelliana de $1984,{ }^{45}$ significa reverter a mídia, utilizando as mesmas armas para também manipular o real, porém, estimulando outras leituras e pontos de vista.

Referindo-se a Robert Lepage, Féral (2008) anuncia a "poética tecnológica", na qual a tecnologia coloca-se a serviço da arte do teatro. De acordo com a pesquisadora, é a tecnologia a responsável pela transformação do cotidiano e do bana em poesia na obra de Lepage. Entretanto, essa apropriação do tecnológico como modo de refletir a cultura contemporânea não exclui o questionamento dos comportamentos do homem atual e de sua relação, exatamente, com as aparelhagens eletrônicas, das quais não se pode escapar. ${ }^{46}$ Buscando exemplos no trabalho de Marianne Weems, ${ }^{47}$ Féral (2008) comenta que, neste caso, a tecnologia surge como personagem principal, cabendo aos performers encará-la como cúmplice e material de composição; não como perigo.

Regurgitofagia, produzido com recursos da bolsa de pesquisa RioArte, no segmento Arte e Tecnologia, explora o tecnológico exatamente nesse sentido: coloca entre artista e público uma interface que os emenda, une homem e máquina, compondo poeticamente afinidades, embates, sentidos, incompreensões, catarses, apreensões e, num paradoxo, distanciamentos. O que comer? O que regurgitar? Como agir a partir da constatação do excesso de informações e estímulos, da ausência de assimilação e reflexão, do estado de aceleração e pressa? - pergunta-se Melamed (2005). Repetir, ou melhor, recriar as sensações de tal realidade contemporânea em cena, com apoio da tecnologia e da consequente troca de choques, parece ser uma trilha para o desvelar de possíveis e o aguçar de incorformismos. Como salienta o artista na obra literária e no teatro: "Regurgitofagia: 'vomitar' os excessos a fim de avaliarmos o que de fato queremos redeglutir. A 'descoisificação' do homem através da consciência crítica, a 'ignorância programada', como quando como quanto quero: ‘extra! extra! a mídia acabou! a mídia acabou!'”. ${ }^{48}$

\section{A PALAVRA EM OUTRO LUGAR}

Conforme Hans-Thies Lehmann (2007), a preponderância do texto no teatro perdeu força a partir dos anos 1970, período da entrada onipresente das mídias na vida cotidiana, permitindo - "quando os meios teatrais, além da língua, [foram] colocados no mesmo nível que o texto e pensáveis mesmo sem o texto"49 - o uso do termo "teatro pós-dramático".

\begin{tabular}{|c|c|c|}
\hline & BELO HORIZONTE & v. 19 \\
\hline
\end{tabular}

49. LEHMANN Teatro pósdramático, p. 81.

\section{Crítica Literária, outras Artes e Midias}


50. VENDRAMINI. O teatro de origem não-dramatúrgica, p. 86.

51. COHEN. Work in progress na cena contemporânea, p. XXIX.

52. COHEN. Work in progress na cena contemporânea, p. XXIV.
Outro tipo de percepção de mundo, simultânea e multifocal, substituía - desde o moderno - aquela linear e sucessiva.

Para Vendramini (2001), se o século XIX foi o período da palavra e da literatura, o XX, fortemente influenciado pela imagem, espelha-se no cinema, na TV e na internet. O autor observa que a narrativa no teatro, progressivamente, tornou-se simplificada e compactada, até se condensar em conceitos. Estes, por sua vez, levam-nos a imagens e ações que superam ou substituem a palavra. "Radicalizando, ou não se tem um texto, ou então o texto passa a ser pretexto para a imagem" ${ }^{50}$ Cohen acrescenta: "o artista contemporâneo imbui-se da missão de criar contexto e não mais texto, obra". ${ }^{51}$

A narrativa já não pode ser organizada "pela lógica aristotélica das ações, pela fabulação, por construções psicológicas de personagem".$^{52}$ Instauram-se, assim, o "hipertexto" e as "textualidades orobóricas", arquitetados pelos acontecimentos cênicos. Ainda que a palavra esteja presente, ela assume outra posição, experimentando, por exemplo, a verborragia. Michel Melamed, em Regurgitofagia, segue esse rumo, parecendo cuspir em um ralo o excesso de palavras da confusa vida contemporânea. A cada "jorro", o ator vai de uma citação à outra, de uma obra à outra, de uma memória à outra.

porque as três marias + os sete mares são os dez mandamentos e as 7 maravilhas do mundo menos os 3 porquinhos

são as 4 estações

ou os 4 cavaleiros do apocalipse ou os 4 mosqueteiros.

porque

os três patetas ou o tamba trio

+ os sete pecados capitais ou os sete gatinhos capitus ou os sete anões,

dariam dez,

bateria nota 10,10 !

mas que menos a lua ou a vida,

dariam nove irmãos para as nove irmãs

e que não passam dos 12 - trabalhos de Hércules ou contos peregrinos

menos 1 four de ás menos dois perdidos numa noite suja.. .

porque os trezentos e sessenta e cinco dias do ano,

menos os jackson five

menos 3 vezes sem juros

menos 26 poetas hoje

os quarenta ladrões, a nona sinfonia e as 500 milhas de Indianápolis

\section{Crítica Literária, outras Artes e Mídias}


53. MELAMED. Regurgitogafia, p. 41.

54. MELAMED. Regurgitogafia, p. 80-1.

55. VENDRAMINI. O teatro de origem não-dramatúrgica, p. 85 nos levariam

- mesmo que alterando a ordem dos fatores ou futuros a lutar 53

Uma vez que o espetáculo nasce a partir de um livro, produzido anteriormente, cabe à cena intensificar as provocações sensoriais suscitadas pelas imagens e pelos sons das poesias. O texto, quente, dá vida ao corpo frio, que já traz dentro si os circuitos nos quais o bios cênico fluirá (BARBA SAVARESE, 1995).

As falas de Melamed não convergem para um sentido lógico. Elas permanecem abertas, desencaixadas. $\mathrm{O}$ artista ironiza: "[...] o complexo de lego: se você é um lego centrado, um legóico, tudo se encaixa”. ${ }^{54}$ De acordo com Vendramini (2001), por muito tempo, o público esteve acostumado à "arte das coisas completas". Agora, precisou "ter contacto com a arte do incompleto, a arte do inacabado; portanto, 'incompleto', 'inacabado' e 'aleatório' deixaram de soar como sinônimos de 'defeito', por serem objetivos procurados de forma voluntária”. ${ }^{55}$

Entretanto, conforme pondera Féral (2008), o teatro está inexoravelmente vinculado a certo tipo de sentido, guiado seja pela palavra, seja pela imagem. Há sempre uma narrativa entre as bordas esfumaçadas do espetáculo, ainda que a mesma atravesse apenas as sensações. Como já mencionamos, na obra performativa, as ações se sobrepõem à representação mimética. É certo que em todo teatro estão presentes os verbos "ser/estar", "fazer" e "mostrar [o que faz]", porém, no caso da performance, eles são algo "primordial e um dos aspectos fundamentais" . ${ }^{56}$ Logo, considerando a impossibilidade de fuga de alguma forma de narrativa, mesmo que centrada na ação, importa pinçar suas especificidades na fase atual. Segundo Féral (2008), a escritura cênica de hoje não mais se revela hierárquica e ordenada, "ela é desconstruída e caótica". ${ }^{57}$

A desvinculação de texto e significado lógico ou referencial, na visão de Cohen (1989), enraíza-se no niilismo próprio dos anos 1980, cujos artistas não acreditavam na cultura ao seu redor. Para eles, não havia mais discurso a ser feito. A palavra estava irremediavelmente vazia. "O discurso é inútil, mentiroso, encobridor (e isso se consubstancia com as descobertas de Freud). Quando esses artistas fazem uso da palavra, eles o fazem no seu sentido mais primitivo, léxico". ${ }^{58} \mathrm{O}$ autor acentua ainda o deslocamento do texto para a posição de mais um elemento, como outro qualquer, da mise em scène. Quando não é totalmente eliminado, ${ }^{59}$ passa a ser utilizado mais por sua sonoridade que por seu conteúdo, mais por seu significante que por seu significado, tal qual acontece na poesia sonora (COHEN, 1989).

EM TESE
BELO HORIZONTE v. 19
N. 1
JAN.-ABR. 2013

FERNANDES. Cena líquida: a arte teatral em aderência e resistência [...]

p. $208-226$
56. FÉRAL. Por uma poética da performatividade: o teatro performativo, p. 201.

57. FÉRAL. Por uma poética da performatividade: o teatro performativo, p. 204.

58. COHEN. Performance como linguagem: criação de um tempo-espaço de experimentação, p. 75.

59. Cabe asseverar que "não é a ausência de textos dramáticos que assegura a existência de um 'teatro pós-dramático', mas o uso que a encenação faz desses
textos" (FERNANDES, 2010, p. 51).

\section{Crítica Literária, outras Artes e Midias}


60. BARBA apud RUFFINI. $A$ arte secreta do ator: dicionário de antropologia teatral, p. 240-1.

61. COHEN. Performance como linguagem: criação de um tempo-espaço de
Por conseguinte, vale salientar que a antiga noção de dramaturgia, estritamente relacionada ao texto, também foi colocada em xeque. Segundo Barba, citado por Ruffini (1995), antes de significar texto falado ou escrito, impresso ou manuscrito, o termo texto fazia referência à "tecedura". Nesse sentido, portanto, não existe espetáculo sem texto, e múltiplas "dramaturgias" se desenrolam em paralelo. "O que diz respeito ao texto (a tecedura ou fio) do espetáculo pode ser definido como dramaturgia, isto é, drama-ergon, o trabalho das ações. A maneira pela qual as ações agem é o enredo". ${ }^{60}$

Outra característica do texto no performativo, de acordo com Cohen (1989), é a repetição. Para o autor, tal elemento exerce a função de um mantra, um som hipnótico, capaz de levar o ouvinte a outros estados de consciência. Em paralelo, a repetição acende a emissão de mensagem subliminar, "que irá ocasionar uma cognição diferente por parte do receptor" ${ }^{61}$ As falas surgem ainda absolutamente simples, comuns, podendo ser extraídas de qualquer tipo de discurso ou fragmento de discurso. Entretanto, trazem em si forte apelo emocional (COHEN, 1989).

Casa comigo que te faço a pessoa mais feliz do mundo. A mais linda, a mais amada, respeitada, cuidada... A mais bem comida $E$ a pessoa mais namorada do mundo e a mais casada. E a mais festas, viagens, jantares... Casa comigo que te faço a pessoa mais realizada profissionalmente. E a mais grávida e a mais mãe. $\mathrm{E}$ a pessoa mais as primeiras discussões. A pessoa mais novas brigas e as discussões de sempre. Casa comigo que te faço a pessoa mais separada do mundo. Te faço a pessoa mais solitária com um filho pra criar do mundo. A pessoa mais foi ao fundo do poço e dá a volta por cima de todas. A mais reconstruiu sua vida. A mais conheceu uma nova pessoa, a mais se apaixonou novamente... casa comigo que te faço a pessoa mais "casa comigo que te faço a pessoa mais feliz do mundo. ${ }^{62}$

No trecho acima, Melamed, de certa maneira, reúne as especificações elencadas por Cohen (1989). Sonoridade, repetição, mensagem subliminar, falas simples e com apelo emocional. $\mathrm{O}$ artista apresenta-se como cria de uma geração de poetas urbanos da década de 1990 que se reuniu por meio do evento CEP 20.000. ${ }^{63}$ Lança mão do que chama de poesia para instaurar o caos e desconstruir envelhecidas e, até mesmo, vanguardistas certezas. "E hoje? Continuamos a 'deglutir vanguardas' ou tem-nos sido empurrada goela abaixo toda a sorte de informações? Conceitos? Produtos?? ${ }^{64}$ Partindo da poesia, Melamed chega à performance.

[...] Creio que ali [Em Regurgitofagia] tinha (Ou tem? Ou sempre terá? Teria?) um misto de poesia falada (da tradição dos anos 70 no Brasil aos Beats e aos trovadores e provençais e à MPB...), passando por teatro e então performance (a presen-
62. MELAMED. Regurgitogafia, p. 55.

63. Centro de Experimentações Poéticas. Evento criado em 1990 pelos escritores Chacal e Guilherme Zarvos. Informações obtidas em Programa Provocações 410 [24 abr. 2009]. Entrevistador: Antonio Abujamra. São Paulo: TV Cultura, 2009.

64. Op. cit., p. 69
EM TESE
BELO HORIZONTE
v. 19
N. 1
JAN.-ABR. 2013
FERNANDES. Cena líquida: a arte teatral em aderência e resistência [...]
P. 208-226

\section{Crítica Literária, outras Artes e Mídias}


65. MELAMED. Entrevista concedida para pesquisa de mestrado. 24 jan. 2013.

66. COHEN. Work in progress na cena contemporânea, p. XXVII. tificação, quebra da mise em scène, etc) e "arte e tecnologia", que compreende a ideia de criação de uma nova interface e não somente a utilização de um objeto tecnológico no campo artístico, o efeito retrovisor... ${ }^{65}$

Segundo Cohen (1998), o contemporâneo explode, sem cerimônias, a divisão estratificada de gêneros. Funde ou entrelaça o trágico, o lírico, o épico e o dramático; "epifania crueldade e paródia convivem na mesma cena" ${ }^{66}$ Melamed compreende a mescla de linguagens como um desejo radical Afinal, as fronteiras estão categoricamente desguarnecidas (PUCHEU, 2007). Livro e espetáculo teatral, assim, conectam-se em um só organismo. No entanto, resta-nos lançar ao ar: se muito partiu da palavra escrita, de que maneira esta influencia, ou desperta, ou dispara a ação? No caminho inverso, como a palavra é influenciada, despertada e disparada pela ação? Qual a dinâmica desse ininterrupto ir e vir? Perguntas que ficarão ainda sem respostas.

Mas há alguns vestígios de saída entre os retorcidos troncos da mata fechada. Melamed chama de poesia os textos criados, primeiramente, para o livro, embora não se incomode em oferecer outro nome, seja qual for, a eles. Poesia prosa poética, dramaturgia, verborragia, hipertexto.

A poesia ali [em Regurgitofagia] é o ponto de partida e chegada - alternando-se entre humor e lirismo. O que não é poesia?
Poesia me parece (e creio mesmo que o dicionário confirma) um adjetivo. Isto é, poesia tem mais relação com um olhar renovado, oxigenado, "novidadista", perplexo, fundamentalmente, sobre toda e qualquer coisa, do que necessariamente com o espaço canônico da literatura, do livro ou mesmo da spoken poetry...

Se concordarmos em compreender como poesias as palavras grafadas do artista, podemos retornar, uma vez mais, a Bauman (2001). O autor assinala, como uma das principais marcas da "modernidade líquida", a ilimitada liberdade. Tudo é possível ao indivíduo. Chacal - para quem o possível apenas se repete, e só o impossível acontece -, curiosamente, elege essa mesma liberdade, "palavra ultrapoluída, superfaturada”, para avaliar a poesia atual. De acordo com ele, como se vê no teatro, os poetas recorrem hoje à "selva selvagem de sons e imagens verbais", à ausência de "regras, fórmulas, igrejas". O autor resume: "Como um químico em seu laboratório, o poeta atual superpõe lâminas de textos, compara, solve e coagula ritmos, métricas e se dedica à grande obra" ${ }^{68}$

Bauman (2001) aborda ainda a questão do tempo. Na pós-modernidade, a época do software revirou a relação tempo-espaço com apenas um clique. Vigoram hoje instantaneidade e imediatismo. Um "agora" que nunca está "aqui". Como já dissemos, a performance, com seu perfil de evento arquiteta o efêmero a favor do tempo interior. O performer,
67. Op. cit.

68. CHACAL Paisagens urbanas, $p$
EM TESE
BELO HORIZONTE
v. 19
N. 1
JAN.ABB. 2013
FERNANDES. Cena liquida: a arte teatral em aderência e resistência [...]
P. $208-226$

\section{Crítica Literária, outras Artes e Midias}


69. STAIGER. Conceptos fundamentales de Poética, p. 14

70. MELAMED. Entrevista concedida para pesquisa de mestrado. 24 jan. 2013 concentrado apenas em suas ações, vive o presente, o legítimo aqui-agora. Pois bem, o lírico, talvez, lance faísca na criação performativa. Segundo Staiger (1966), este é o gênero que melhor traduz essa temporalidade íntima, ou seja, esse contato com o corpo, o orgânico, as sensações, o fluxo livre de pensamentos de um determinado instante. É a manifestação mais pura da alma, mas também a mais insondável, indecifrável. "O lírico funde ou derrete. Se opõe a todo sólido e por isso é também o mais instável”"99 (grifo nosso). O que o lírico parece liquefazer, assim como o performativo, é o sólido "concretado" pelo excesso de líquido: a pressa, os exageros, enfim, os descabimentos do mundo atual.

De todo modo, Melamed não se preocupa com os gêneros e seus limites. Prefere mover-se incessantemente, desesperadamente, entre a paixão e paralisia. "Não vejo divisão entre as linguagens. [...] Objetivando: o desespero. Existe um desespero em interferir. Essa interferência precisa de um estado mínimo de alegria e fé e paixão. Daí a paixão é febril e traz o desespero que é paralisante de novo. Então a faísca é o pêndulo entre a paixão e a paralisia" ${ }^{70}$

\section{CONSIDERAÇÕES FINAIS}

Os novos tempos, fluidos e caoticamente móveis, solapam a noção de fronteira. Do moderno ao pós-moderno do happening à performance e desta ao teatro performativo, das vanguardas ao teatro contemporâneo, do dramático ao "pós-dramático", não há limites precisos. Não há solidez nas zonas de transição.

Também livres são as passagens entre arte e vida. Aqui, restam-nos duas abordagens. Primeiramente, é necessário asseverar que o fazer artístico não se dissocia dos acontecimentos históricos, sendo sempre influenciado pelos modos de compreensão do mundo e pelo comportamento dos homens, pelo discorrer dos eventos em sociedade. No sentido inverso, as criações artísticas também agem sobre o mundo, questionando-o. Há ainda a constatação de que, no teatro de todos os tempos, arte e vida sempre travaram diálogos. As obras performativas levam ao cume essa oscilação, estando o performer, permanentemente, na vibração entre cena e não-cena, entre personagem, indivíduo e outras "máscaras".

O teatro parece se beneficiar, conforme Féral (2008), com as aquisições ofertadas pela performance. Abrindo espaço para imagem, mídia e tecnologia, o fazer teatral aproxima-se da ideia de evento, dando ênfase às ações do ator-autor, ao momento presente, a riscos e imprevistos e a resultados não programados. Consequentemente, a recepção problematiza-se, ficando a cargo do público encontrar, se assim desejar, possíveis sentidos.
EM TESE
BELO HORIZONTE
v. 19
N. 1
JAN.-ABr. 2013 FERNANDES. Cena líquida: a arte teatral em aderência e resistência [...]
p. 208-226

\section{Crítica Literária, outras Artes e Mídias}


O texto e a palavra não desaparecem no performativo. O primeiro, entretanto, desvincula-se da dramaturgia, uma vez que esta também se revela unida a outros elementos teatrais. Na atualidade, "contexto" e "hipertexto" se sobrepõem ao texto. Da mesma forma, a palavra escapole da narrativa linear e lógica, preferindo a verborragia, a sonoridade, a incompletude e oferecendo lugar à imagem e a outros sons.

Michel Melamed lança mão do que denomina como poesia para vencer as fronteiras que ligam teatro, performance, literatura, artes visuais e tecnologia. O lírico, por traduzir a temporalidade íntima, faz-se trilho ao vagão da performance, acelerando as aberturas de sentido. Tal qual o performativo, a poesia de hoje enfrenta a liberdade absoluta, o recorte, a imagem, o excesso, o descabido. Regurgitofagia, desse modo, vale-se da palavra poética para a construção de um discurso híbrido, verborrágico e resistente, capaz de intensificar a presença do ator-autor.

\section{REFERÊNCIAS}

BARBA, Eugenio. A canoa de papel. São Paulo: Hucitec, 1994.

BARBA, Eugenio; SAVARESE, Nicola. A arte secreta do ator: dicionário de antropologia teatral. Campinas: Huciter, 1995.

BAUMAN, Zygmunt. Medo líquido. Rio de Janeiro: Zahar, 2006
BAUMAN, Zygmunt. Modernidade líquida. Rio de Janeiro: Zahar, 2001

CHACAL. Paisagens urbanas. In: PEDROSA, Celia (org.). Mais poesia hoje. Rio de Janeiro: 7Letras, 2000. p. 52-58.

COHEN, Renato. Work in progress na cena contemporânea. São Paulo: Perspectiva - Editora da Universidade de São Paulo, 1998.

COHEN, Renato. Performance como linguagem: criação de um tempo-espaço de experimentação. São Paulo: Perspectiva Editora da Universidade de São Paulo, 1989.

FABIÃO, Eleonora. Condução de trabalho: pedagogias, treinamentos e processos criativos. II Simpósio de Reflexões Cênicas Contemporâneas, Lume/Unicamp, Campinas, 20 fev. 2013

FÉRAL, Josette. Por uma poética da performatividade: o teatro performativo. Sala Preta - Revista do PPG em Artes Cênicas ECA/USP, São Paulo, v.8, n.1, p. 197-210, 2008. Disponível em: $<$ http://www.revistasalapreta.com.br/index.php/salapreta/article/ view/260 > . Acesso em: 03 jan. 2013.

FERNANDES, Silvia. Teatralidades contemporâneas. São Paulo: Perspectiva, 2010.

GLUSBERG, Jorge. A arte da performance. São Paulo: Perspectiva, 2011.

HALL, Stuart. A identidade cultural na pós-modernidade. Rio de Janeiro: DP\&A Editora, 2006.

\section{Crítica Literária, outras Artes e Mídias}


LEHMANN, Hans-Thies. Teatro pós-dramático. São Paulo: Cosac Naify, 2007

MELAMED, Michel. Entrevista concedida para pesquisa de mestrado. 24 jan. 2013 (E-mail).

MELAMED, Michel. Íntegra da entrevista publicada no jorna O Globo. Michel Melamed Blog, Rio de Janeiro, 10 nov.

2010. Disponivel em: <http://michelmelamed wordpress.

com/2010/11/10/hello-world/>. Acesso em: 13 out. 2012.

MELAMED, Michel. Programa Provocações 410 [24 abr.

2009]. Entrevistador: Antonio Abujamra. São Paulo: TV

Cultura, 2009. Disponível em: <http://www.youtube.com/

watch?v=V0qO5kXXSsA>. Acesso em: 24 out. 2012

MELAMED, Michel. Regurgitofagia. Rio de Janeiro: Objetiva, 2005

PUCHEU, Alberto. A fronteira desguarnecida: poesia reunida 1993-2007. Rio de Janeiro: Beco do Azougue, 2007. Disponíve em: <http://www.albertopucheu.com.br/pdf/livros/fronteira

poesias.pdf $>$. Acesso em: $10 \mathrm{dez} .2012$.

MELAMED, Michel. Escritos da frequentação. Rio de Janeiro: Ed. Paignion, 1995. Disponível em: <http://www.albertopucheu. com.br/pdf/livros/escritos da frequentacao.swf $>$. Acesso em: 10 dez. 2012.

RUFFINI, Franco. A cultura do texto e a cultura do palco. In: BARBA, Eugenio; SAVARESE, Nicola. A arte secreta do ator: dicionário de antropologia teatral. Campinas: Huciter, 1995, p. 238-43.
STAIGER, Emil. Conceptos fundamentales de Poetica. Madrid: Ediciones Rialp S. A., 1966.

VENDRAMINI, José Eduardo. O teatro de origem nãodramatúrgica. Sala Preta - Revista do PPG em Artes Cênicas - ECA/USP, São Paulo, v.1, n.1, p. 81-86, 2001. Disponível em: <http://www.revistasalapreta.com.br/index.php/salapreta/article/ view/43/41 > . Acesso em: 12 dez. 2012.

\section{Crítica Literária, outras Artes e Mídias}

